\title{
Psychological factors and genetic characteristics of rural cannabis users
}

\author{
Milena Lachowicz, ${ }^{1, \mathrm{~B}-\mathrm{F}}$, Jolanta Chmielowiec ${ }^{2, \mathrm{~B}-\mathrm{C}, \mathrm{F} \oplus}{ }^{\oplus}$, Krzysztof Chmielowiec $^{2, \mathrm{~B}-\mathrm{C}, \mathrm{F} \oplus}{ }^{\text {, }}$ \\ Aleksandra Suchanecka ${ }^{3, B-F} \oplus$, Monika Michałowska-Sawczyn ${ }^{1, B-C, F \oplus}$, Artur Mierzecki ${ }^{4, E-F} \oplus$, \\ Bożena Mroczek ${ }^{5, C-F}$, Anna Grzywacz ${ }^{3 A, C-F} \oplus$ \\ ${ }^{1}$ Department of Physical Education and Social Science, University of Physical Education and Sport, Gdańsk, Poland \\ 2 Department of Hygiene and Epidemiology, Collegium Medicum, University of Zielona Góra, Poland \\ ${ }^{3}$ Independent Laboratory of Health Promotion of the Pomeranian Medical University, Szczecin, Poland \\ ${ }^{4}$ Independent Laboratory of Family Physician Education, Pomeranian Medical University, Szczeczin, Poland \\ ${ }^{5}$ Department of Humanities in Medicine, Pomeranian Medical University, Szczecin, Poland \\ A - Research concept and design, B - Collection and/or assembly of data, C - Data analysis and interpretation, \\ $D$ - Writing the article, E - Critical revision of the article, F - Final approval of article
}

Lachowicz M, Chmielowiec J, Chmielowiec K, Suchanecka A, Michałowska-Sawczyn M, Mierzecki A, Mroczek B, Grzywacz A. Psychological factors and genetic characteristics of rural cannabis users. Ann Agric Environ Med. 2020; 27(2): 260-268. doi: 10.26444/aaem/119939

\begin{abstract}
Introduction. Marijuana is one of the most widely used psychoactive substance. There is evidence of genetic predisposition for addiction.

Objective. The aim of the study is to evaluate personality traits measured by the NEO Five-Factor Inventory and State-Trait Anxiety Inventory, combined with analysis of Tag1B rs1079597 and Tag1D rs1800498 located in the DRD2 gene.

Materials and method. The study group consisted of 214 rural cannabinoid users and 301 controls. The same psychometric test and real-time PCR genotyping were performed in both studied groups.

Results. The values of Anxiety state, Anxiety trait, NEO FFI: Neuroticism and Openness in the rural cannabis using group were significantly higher than in the control group. On the other hand, lower values were observed among rural people using cannabis compared to the control group for NEO FFI: Extraversion, Agreeability and Conscientiousness. In the Anxiety trait subscale, a 2\% association with the polymorphism DRD2 Tag1B rs1079597 was detected in subjects using cannabis. However, for the DRD2 Tag1D rs1800498, there was no effect on the differences in personality traits between rural cannabis users and the control group.

Conclusions. The study shows differences in personality traits between the cannabis using group and controls. Interaction between genetic factors and personality traits was also detected. The association showing the combination of psychological characteristics and genetic variants can bring us closer to the overall picture of the issue of marijuana addiction.
\end{abstract}

\section{Key words}

addiction; polymorphism; personality traits; cannabis

\section{INTRODUCTION}

Marijuana addiction - a complex problem. Marijuana, abundant with tetrahydrocannabinol/THC, is the psychoactive substance used most frequently worldwide. Global usage of cannabis has reached the level of 180 million people, of whom approximately $9 \%$ become addicted, especially during adolescence when the number of addicts increases to $16 \%$, and accounts for $50 \%$ if its usage daily $[1,2]$. Between $1998-2017$, the number of cannabis users increased by $30 \%$ [3].

Analysis of family data indicates that cannabis use, abuse and dependence, is aggregated in families $[4,5,6,7,8,9]$. Currently conducted twin studies have considered particular phases of cannabis involvement and noticed that genetic and environmental factors are elements influencing individual differences in cannabis involvement $[1,2,10,11,12,13]$. Ggenetic studies of many variables, however, have not covered many aspects of the relationship between cannabis and other hard drugs $[14,15,16,17,18]$. The increasing

Address for correspondence: Anna Grzywacz, Independent Laboratory of Health Promotion of the Pomeranian Medical University, Szczecin, Poland

E-mail: grzywacz.anna.m@gmail.com

Received: 25.02.2020; accepted: 31.03.2020; first published: 15.05 .2020 amount of genomic data from large-scale linkage studies (e.g. Collaborative Study on the Genetics of Alcoholism: COGA), has created the need for searching for genome regions, and even candidate genes that may be related with the genetic etiology of cannabis involvement.

Behavioural traits, among them cannabis involvement, are conditioned by many factors, i.e. numerous genetic and environmental factors are connected with its incidents, as well as individually as interactively, and polygenetic influence is observed which means that numerous genes influence genetic variation with different strength. It is a fact that the gene causing cannabis use or cannabis dependence cannot easily determined as is the case, for example, in sickle cell anemia which correspondence with a Val6Glu mutation within the $\beta$-globin gene $[19,20]$. In simple words, the extinction of cannabis, due, for instance, to some kind of plague that would decrease the number of Cannabis indica plants, would result in the absence of cannabis use, irrespective of genetic predispositions. Hence, it can be assumed that the defined trait is conditioned by the environmental and heritable predispositions, and there would then be no cannabis use. Personality traits or anxiety may become a predisposing factor for addiction. Additionally, the interaction of personality and gene variants need to be 
taken into account. Hence, the presented study concentrates on the analysis of personality traits, anxiety as a trait and as a state among individuals with marijuana addiction. There is no doubt that strong evidence was observed for a genetic basis for this addiction; however, the search continues for a set of genes or polymorphisms responsible for this disorder. Nonetheless, psychological factors are consider as another important element in marijuana addiction. Moreover, the patient's state of anxiety should also be taken into consideration [21], and the reduction of marijuana usage by an individual can be subjectively achieved. Research on personality traits in cannabis users show a high openness score in this group [22, and low extraversion [23] and agreeableness [24]. Additionally, impulsiveness, as well as unusual perception and eccentricit, were associated with cannabis use [25]. Recent GWAS analysis showed positive genetic correlations with substance use and phenotypes dependence (smoking, alcohol), as well as with mental health phenotypes (schizophrenia, ADHD). Interestingly, positive genetic correlations were also found with openness to experience, risk-taking behaviour, and negative correlations with conscientiousness [26]. However, biological factors cannot be ignored; hence, the current analysis is based on both genetic and biological factors occurring among patients with marijuana addiction.

Cannabinoid receptor 1 (CNR1) and cannabinoid receptor 2 (CNR2) are both activated only by binding cannabis [27]. CNR1 is expressed mainly in the brain, whereas CNR 2 mostly in the cells of the immune system and in aematopoietic cells $[28,29]$. The main function of CNR1 is to regulate mesolimbic dopaminergic transmission in the brain areas that are also engaged in reinforcing the effects of the abused drugs [30]. The action of endogenous cannabinoids can be mimicked by cannabis and influence the action of dopamine [31]. It is a significant fact that the neurobiological mechanism underlying the actions of cannabis and other abused drugs, is primarily connected with dopamine pathway activation [32]. The dopamine system is known to be regulated by numerous genes, and the DRD2 gene is one of the most often analyzed in connection with addictive disorders [33].

Mice in which the lower level of DRD2 mRNA expression was observed in the nucleus accumbens and the hippocampus, are more prone to alcohol consumption than the one with higher expression [34]. Moreover, numerous studies noticed a relationship between Taq1 polymorphism and substance dependence. Several studies indicated an association between Taq1B polymorphism and alcoholism, cocaine dependence, smoking status, and polysubstance abuse [35, 36, 37, 38].

Addiction should be considered as a multifactorial disease, and its analysis should combine both the genetic component and psychological factors, and preferably an interaction between the two. Considering the mentioned presupposition, it was assumed that psychological factors might be analyzed in relation with both anxiety and personality traits.

The Five Factor Model, also known as Big Five personality traits, has been one of the most popular tools among researchers dealing with personality disorders for the last decades $[39,40,41,42]$. The model was based on studies of the personality structure assuming first some elements of 'healthy' personality. However, at the same time, the model considers the specific type of personality characterized with extremely low or high level of the 'normal' trait' that might correspond with a personality disorder. Such a situation is frequently observed in the case of addiction. The NEO-FFI questionnaire, also known as 'Big Five', distinguishes the following factors which describe the human personality: openness to experience, conscientiousness, extraversion, agreeableness and, neuroticism [43]. A characteristic feature of neuroticism is a high tendency to mood changes with numerous negative emotions, such as anxiety, worry, anger, fear, frustration, jealousy, guilt, envy, depressive moods and loneliness $[44,45]$.

Neuroticism, similar to harm avoidance (HA), is considered to be connected with the serotonergic system [46, 47]. Another personality trait, Openness, is often linked with intellect and diverse thinking. The functioning of dopamine, mainly in the prefrontal cortex, also influences that trait [48]. The other element considered is Conscientiousness, the ability to control impulses and act in a socially accepted manner [49].

Extraversion is characterized by sociability, assertiveness and excitability. The main feature of extraversion is shown in the form of being more dominant in a social surrounding, in opposition to those who seem to be less dominant [50]. Agreeableness, however, is a tendency towards compassion and cooperation, and also includes attributes such as altruism, trust, and other pro-social behaviors.

State-Trait Anxiety Inventory (STAI) is often applied in addiction research. It is a tool used to measure both the state and trait of anxiety [51].

\section{OBJECTIVE}

The main aim of this study is to analyze the Tag1B rs1079597 and Tag1D rs1800498 polymorphisms in the DRD2 gene in a group of rural individuals addicted to marijuana and in a control group, with special attention being paid to personality traits analyzed by application of the NEO-FFI and STAI questionnaires.

\section{MATERIALS AND METHOS}

Subjects. 515 male volunteers comprised the study group of cannabis dependent rural individuals $(n=214$; mean age $=27.46 ; \mathrm{SD}=6.12$ ), and a group of non-dependent controls $(n=301 ;$ mean age $=22.14 ; \mathrm{SD}=4.57)$. After obtaining approval fom the Bioethics Committee of the Pomeranian Medical University in Szczecin (KB-0012/106/16), and informed, written consent from the participants, the study was conducted in the Independent Laboratory of Health Promotion. Cannabis dependent rural patients were recruited after at least 3 months abstinence in addiction treatment facilities. The dependent rural patients and control subjects were examined by a psychiatrist and the by using the Mini International Neuropsychiatric Interview (M.I.N.I.), the NEO Five-Factor Personality Inventory (NEO-FFI), and the State-Trait Anxiety Inventory (STAI) questionnaires.

STAI Questionnaire. A tool for determining the trait of anxiety (A-Trait) that be defined as a continuous and long-lasting disposition to experience, stress, worries and discomfort, and the state of anxiety (A-state) that corresponds with discomfort, fear, and the arousal of the autonomic nervous system which occurs temporarily in relation to a particular situation. The Personality Inventory (NEO Five- 
Factor Inventory, NEO-FFI) represents 6 components for each of the five traits:

1) Extraversion - Positive Emotion, Warmth, Gregariousness, Activity, Excitement Seeking, Assertiveness;

2) Agreeableness - Tender-mindedness, Trust, Altruism, Straightforwardness, Compliance, Modesty;

3) Openness to experience - Aesthetics, Feelings, Fantasy, Actions, Ideas, Values;

4) Conscientiousness - Deliberation, Competence, Dutifulness, Order, Achievement striving, Self-discipline;

5) Neuroticism - Anxiety, Vulnerability to stress, Hostility, Self-consciousness, Impulsiveness, Depression [52].

Data from the NEO-FFI and STAI inventories were provided in the form of sten scores. Polish norms for adults were used to convert raw scores into the sten scale. The assumption was: stens $1-2=$ very low scores; $3-4=$ low scores; $5-6=$ average scores; $7-8=$ high scores; $9-0=$ very high scores.

The history of dependence was collected based on the ICD-10 Polish version, authors' survey, and medical history of individuals. DNA was collected from venous blood.

Genotyping. Genomic DNA was extracted from venous blood using standard procedures, and the genotyping carried out with the real-time PCR method.

LightCycler ${ }^{\circledast} 480$ II System (Roche Diagnostic, Basel, Switzerland) was applied to convert the fluorescence resonance energy into genotype data. Data connected with DRD2 gene polymorphism were obtained in the following conditions: PCR was performed according to standard procedures; peaks were observed at $57.41{ }^{\circ} \mathrm{C}$ in the case of $\mathrm{G}$ allele and at $62.25^{\circ} \mathrm{C}$ for the A allele for the rs1079597, and at $57.87^{\circ} \mathrm{C}$ for the $\mathrm{T}$ allele and at $66.34^{\circ} \mathrm{C}$ for the $\mathrm{C}$ allele for the rs 1800498 .

Statistical Analysis. Concordance between the genotype frequency distribution and Hardy-Weinberg equilibrium (HWE) was tested with HWE software http://www.oege. org/ software/hwe-mr-calc.html). The relationship between DRD2 Tag1B rs1079597 and DRD2 Tag1D rs1800498 variants, cannabis users and control subjects, and the NEO Five Factor Inventory (NEO-FFI), were analyzed for variables analysis of Factor effects ANOVA (NEO-FFI/ scale STAI/ × genetic feature $\times$ control and cannabis rural users subjects $\times$ (genetic feature cannabis rural users subjects). When considering the homogeneity of variance, it was also observed to be satisfied (Levene test $\mathrm{p}>0.05$ ). However, the observed distribution did not satisfy the condition of normality. The NEO Five Factor Inventory (Neuroticism, Extraversion, Openness, Agreeability Conscientiousness) were tested and compared applying the U Mann-Whitney test. DRD2 Tag1B rs1079597 and DRD2 Tag1D rs1800498 genotype frequencies between healthy control individuals and rural cannabis users were checked with the chi square test. All computations were performed using STATISTICA 13 (Tibco Software Inc, Palo Alto, CA, USA) for Windows (Microsoft Corporation, Redmond, WA, USA).

\section{RESULTS}

The frequency distributions were in accordance with the HWE, both in the rural cannabis users and the control subjects (Supplementary data, Tab. 1, Tab. 2).

DRD2 Tag1B rs1079597 genotype frequencies and DRD2 Tag1D rs1800498 genotype occurrence in the tested sample did not vary between rural cannabis users subjects and control subjects (Tab. 1, Tab. 2).

Table 1. Frequency of genotypes of the DRD2 Tag1B rs1079597 gene polymorphism in rural cannabis users and in controls

\begin{tabular}{lccccc}
\hline \multirow{2}{*}{ Group } & \multicolumn{5}{c}{ DRD2 Tag1B rs1079597 } \\
& $\mathrm{G} / \mathrm{G}$ & $\mathrm{A} / \mathrm{G}$ & $\mathrm{A} / \mathrm{A}$ & $\mathrm{G}$ & $\mathrm{A}$ \\
& $\mathrm{N}(\%)$ & $\mathrm{N}(\%)$ & $\mathrm{N}(\%)$ & $\mathrm{N}(\%)$ & $\mathrm{N}(\%)$ \\
\hline Rural cannabis users & 138 & 67 & 9 & 343 & 85 \\
$\mathrm{~N}=214$ & $(0.64)$ & $(0.31)$ & $(0.04)$ & $(0.80)$ & $(0.20)$ \\
\hline Control & 207 & 83 & 11 & 497 & 105 \\
$\mathrm{~N}=301$ & $(0.69)$ & $(0.27)$ & $(0.04)$ & $(0.83)$ & $(0.17)$ \\
\hline$X^{2}$ & & 1.04 & & \multicolumn{3}{c}{.97} \\
$p$ value & & 0.595 & & \multicolumn{3}{c}{0.324} \\
\hline
\end{tabular}

$\mathrm{P}$ - statistical significance $\mathrm{x} 2$ test; $\mathrm{N}$ - number of subjects

Table 2. Frequency of genotypes of the DRD2 Tag1D rs1800498 gene polymorphism in rural cannabis users and in controls

\begin{tabular}{lccccc}
\hline \multirow{2}{*}{ Group } & \multicolumn{5}{c}{$\begin{array}{c}\text { DRD2 Tag1D rs1800498 } \\
\text { Genotypes Alleles }\end{array}$} \\
\cline { 2 - 6 } & $\mathrm{T} / \mathrm{T}$ & $\mathrm{C} / \mathrm{T}$ & $\mathrm{C} / \mathrm{C}$ & $\mathrm{T}$ & $\mathrm{C}$ \\
& $\mathrm{N}(\%)$ & $\mathrm{N}(\%)$ & $\mathrm{N}(\%)$ & $\mathrm{N}(\%)$ & $\mathrm{N}(\%)$ \\
\hline Rural cannabis users & 65 & 105 & 44 & 235 & 193 \\
$\mathrm{~N}=214$ & $(0.30)$ & $(0.49)$ & $(0.21)$ & $(0.55)$ & $(0.45)$ \\
\hline Control & 108 & 142 & 51 & 358 & 244 \\
$\mathrm{~N}=301$ & $(0.36)$ & $(0.47)$ & $(0.17)$ & $(0.59)$ & $(0.41)$ \\
\hline$X^{2}$ & & 2.11 & & \multicolumn{3}{c}{2.13} \\
$p$ value & & 0.348 & & \multicolumn{3}{c}{0.144} \\
\hline
\end{tabular}

$\mathrm{P}$ - statistical significance $\mathrm{X} 2$ test; $\mathrm{N}$ - number of subjects

The means and standard deviations for all NEO Five Factor Inventory scales and STAI state and trait scale for rural cannabis users and control subjects are presented in Table 3.

Table 3. STAI and NEO Five Factor Inventory results (sten scale) in group of healthy controls and in group of rural cannabis users

\begin{tabular}{|c|c|c|c|c|}
\hline $\begin{array}{l}\text { STAI / NEO Five Factor } \\
\text { Inventory }\end{array}$ & $\begin{array}{l}\text { Rural cannabis users } \\
\qquad(\mathrm{N}=214)\end{array}$ & $\begin{array}{l}\text { Control } \\
(\mathrm{N}=301)\end{array}$ & Z & $\mathrm{p}$ Value \\
\hline STAI state/scale & $\begin{array}{c}5.86 \\
(2.47)\end{array}$ & $\begin{array}{c}4.69 \\
(2.14)\end{array}$ & 5.535 & 0.000 \\
\hline STAI trait/scale & $\begin{array}{c}7.15 \\
(2.38)\end{array}$ & $\begin{array}{c}5.16 \\
(2.18)\end{array}$ & 8.733 & 0.000 \\
\hline Neuroticism/scale & $\begin{array}{c}6.74 \\
(2.27)\end{array}$ & $\begin{array}{c}4.67 \\
(2.01)\end{array}$ & 9.573 & 0.000 \\
\hline Extraversion/scale & $\begin{array}{c}5.74 \\
(2.10)\end{array}$ & $\begin{array}{c}6.37 \\
(1.97)\end{array}$ & -3.253 & 0.001 \\
\hline Openness/scale & $\begin{array}{c}5.04 \\
(2.00)\end{array}$ & $\begin{array}{c}4.53 \\
(1.61)\end{array}$ & 2.835 & 0.004 \\
\hline Agreeability/scale & $\begin{array}{c}4.29 \\
(1.97)\end{array}$ & $\begin{array}{c}5.60 \\
(2.09)\end{array}$ & -6.825 & 0.000 \\
\hline Conscientiousness/scale & $\begin{array}{c}5.49 \\
(2.25)\end{array}$ & $\begin{array}{c}6.08 \\
(2.15)\end{array}$ & -2.845 & 0.004 \\
\hline
\end{tabular}

$\mathrm{P}$ - statistical significance; $\mathrm{Z}$ - U Mann-Whitney test;i $\mathrm{N}$ - number of subjects 
Significant between-group differences are marked in bold.

When comparing the control group, no statistically significant difference was observed in the occurrence of genotypes for the DRD2 Tag1B rs1079597 gene in rural cannabis users (G/G 0.64 vs. G/G 0.69, A/G 0.31 vs. A/G 0.27, A/A 0.04 vs. A/A $0.04, \chi 2=1.04 ; \mathrm{p}=0.595)$. This was similar in the case of a statistically significant difference in the frequency for the DRD2 Tag1B rs1079597 alleles between the rural cannabis users and the controls (G 0.80 vs. G 0.83 , A 0.20 vs. A $\left.0.17, \chi^{2}=.97 ; \mathrm{p}=0.324\right)$. When comparing the control group and rural cannabis users, no statistically significant differences were observed in the genotype frequency for the DRD2 Tag1D rs1800498 gene (T/T 0.30 vs. T/T 0.36, C/T 0.49 vs. C/T 0.47, C/C 0.21 vs. C/C 0.17, $\chi 2=2.11 ; \mathrm{p}=0.348$ ), nor was there a statistically significant difference in the frequency for the DRD2 Tag1D rs1800498 alleles between the rural cannabis users and the control group ( $\mathrm{T} 0.55$ vs. T $0.59, \mathrm{C} 0.45$ vs. C $0.41, \chi 2=2.13 ; \mathrm{p}=0.144)$.

When analyzing the controls and the study subjects, for the latter, definitely increased scores were observed for the STAI state scale (M 5.86 vs. M 4.69; p <0.001), STAI trait scale
(M 7.15 vs. M 5.16; p <0.001), NEO Five Factor Inventory scale of Neuroticism (M 6.74 vs. M 4.67; p <0.001), and the NEO Five Factor Inventory scale of Openness (M 5.04 vs. $\mathrm{M} 4.53$; $\mathrm{p}<0.01$ ).

Differences were observed between the controls and the study group which showed significantly lower scores on the NEO Five Factor Inventory scale of Extraversion (M 5.74 vs. M 6.37; $\mathrm{p} \leq 0.001)$, the NEO Five Factor Inventory scale of Agreeability (M 4.29 vs. M 5.60; p <0.001), and the NEO Five Factor Inventory scale of Conscientiousness (M 5.49 vs. M 6.08; $\mathrm{p}<0.01)$. The results of $2 \times 3$ factorial ANOVA of the NEO Five-Factor Personality Inventory (NEO-FFI) and the State-Trait Anxiety Inventory (STAI) sten scales are shown in d in Tables 6 . and 7. Significant results were noted when comparing STAI trait scale for DRD2 Tag1B rs1079597 $\left(\mathrm{F}_{2,510}=5.62 ; \mathrm{p}<0.01\right)$, which accounted for $2.2 \%$ of variance. Significant results wewre also noted when comparing groups (rural cannabis users vs controls) in relation to NEO FFI Extraversion and DRD2 Tag1D rs1800498 $\left(\mathrm{F}_{2,510}=3.88\right.$; $\mathrm{p}<0.05$ ), which accounted for $1.5 \%$ of variance (Fig. 1 ). Posthoc analysis is shown in Tables 4 and 5.

Table 4. Differences in DRD2 Tag1B rs1079597 and STAI /NEO Five Factor Inventory between healthy control subjects and rural cannabis users

\begin{tabular}{|c|c|c|c|c|c|c|c|c|c|}
\hline \multirow{3}{*}{$\begin{array}{l}\text { STAI / NEO Five Factor } \\
\text { Inventory }\end{array}$} & \multirow{3}{*}{$\begin{array}{c}\text { rural cannabis } \\
\text { users } \\
(N=214)\end{array}$} & \multirow{3}{*}{$\begin{array}{l}\text { control } \\
(N=301)\end{array}$} & \multicolumn{3}{|c|}{ DRD2 Tag1B rs1079597 } & \multicolumn{4}{|l|}{ Factor Effects ANOVA } \\
\hline & & & $G / G$ & $A / G$ & $A / A$ & & & & \\
\hline & & & $(N=345)$ & $(N=150)$ & $(N=20)$ & factor & $F$ (p value) & $\eta^{2}$ & $\begin{array}{c}\text { power } \\
\text { (alfa }=0,05)\end{array}$ \\
\hline \multirow{4}{*}{ STAl state /scale } & \multirow{4}{*}{$\begin{array}{l}M=5.86 \\
S D=2.47\end{array}$} & \multirow{4}{*}{$\begin{array}{l}M=4.69 \\
S D=2.14\end{array}$} & \multirow{4}{*}{$\begin{array}{l}M=5.13 \\
S D=2.37\end{array}$} & \multirow{4}{*}{$\begin{array}{l}M=5.11 \\
S D=2.29\end{array}$} & \multirow{4}{*}{$\begin{array}{l}M=6.30 \\
S D=2.34\end{array}$} & intercept & $F_{1,510}=897.34(p=.000)$ & .639 & 1.000 \\
\hline & & & & & & cannabis /control & $F_{1,510}=9.641(p=.002)$ & .019 & .873 \\
\hline & & & & & & $D R D 2 \operatorname{Tag} 1 B$ & $\mathrm{~F}_{2,510}=2.44(\mathrm{p}=.088)$ & .009 & .491 \\
\hline & & & & & & cannabis/control x DRD2 Tag1B & $F_{2,510}=0.24(p=.789)$ & .0009 & .087 \\
\hline \multirow{4}{*}{ STAI trait /scale } & \multirow{4}{*}{$\begin{array}{l}M=7.15 \\
S D=2.38\end{array}$} & \multirow{4}{*}{$\begin{array}{l}M=5.16 \\
S D=2.18\end{array}$} & \multirow{4}{*}{$\begin{array}{l}M=6.01 \\
S D=2.49\end{array}$} & \multirow{4}{*}{$\begin{array}{l}M=5.70 \\
S D=2.34\end{array}$} & \multirow{4}{*}{$\begin{array}{l}M=7.50 \\
S D=2.48\end{array}$} & intercept & $F_{1,510}=1267.11(p=.000)$ & .715 & 1.000 \\
\hline & & & & & & cannabis /control & $F_{1,510}=27,23(p=.000)$ & .051 & .999 \\
\hline & & & & & & $D R D 2 \operatorname{Tag} 1 B$ & $F_{2,510}=5.62(p=.004)$ & .022 & .858 \\
\hline & & & & & & cannabis/control x DRD2 Tag1B & $\mathrm{F}_{2,510}=.05(\mathrm{p}=.948)$ & .0002 & .058 \\
\hline \multirow{4}{*}{$\begin{array}{l}\text { NEO FFI } \\
\text { Neuroticism /scale }\end{array}$} & \multirow{4}{*}{$\begin{array}{l}M=6.74 \\
S D=2.27\end{array}$} & \multirow{4}{*}{$\begin{array}{l}M=4.67 \\
S D=2.01\end{array}$} & \multirow{4}{*}{$\begin{array}{l}M=5.52 \\
S D=2.42\end{array}$} & \multirow{4}{*}{$\begin{array}{l}M=5.42 \\
S D=2.20\end{array}$} & \multirow{4}{*}{$\begin{array}{l}M=6.25 \\
S D=2.31\end{array}$} & intercept & $F_{1,510}=1138.80(p=.000)$ & .692 & 1.000 \\
\hline & & & & & & cannabis /control & $F_{1,510}=27.95(p=.000)$ & .052 & .999 \\
\hline & & & & & & $D R D 2 \operatorname{Tag} 1 B$ & $F_{2,510}=1.25(p=.288)$ & .005 & .271 \\
\hline & & & & & & cannabis/control x DRD2 Tag1B & $\mathrm{F}_{2,510}=0.80(\mathrm{p}=.451)$ & .003 & .186 \\
\hline \multirow{4}{*}{$\begin{array}{l}\mathrm{NEO} F \mathrm{FI} \\
\text { Extraversion /scale }\end{array}$} & \multirow{4}{*}{$\begin{array}{c}5.74 \\
\mathrm{SD}=2.10\end{array}$} & \multirow{4}{*}{$\begin{array}{l}M=6.37 \\
S D=1.97\end{array}$} & \multirow{4}{*}{$\begin{array}{l}M=6.04 \\
S D=2.03\end{array}$} & \multirow{4}{*}{$\begin{array}{l}M=6.22 \\
S D=2.11\end{array}$} & \multirow{4}{*}{$\begin{array}{l}M=6.45 \\
S D=1.90\end{array}$} & intercept & $F_{1,510}=1388.44(p=.000)$ & .732 & 1.000 \\
\hline & & & & & & cannabis /control & $F_{1,510}=5.11(p=.024)$ & .010 & .617 \\
\hline & & & & & & $D R D 2 \operatorname{Tag} 1 B$ & $\mathrm{~F}_{2,510}=.69(\mathrm{p}=.500)$ & .003 & .167 \\
\hline & & & & & & cannabis/control x DRD2 Tag1B & $F_{2,510}=.61(p=.541)$ & .002 & .153 \\
\hline & & & & & & intercept & $F_{1,510}=1082.03(p=.000)$ & .681 & 1.000 \\
\hline NEO FFI & $M=5.04$ & $M=4.53$ & $M=4.70$ & $M=4.84$ & $M=4.75$ & cannabis /control & $F_{1,510}=5.93(p=.015)$ & .012 & .681 \\
\hline Openness/scale & $\mathrm{SD}=2.00$ & $\mathrm{SD}=1.61$ & $\mathrm{SD}=1.80$ & $\mathrm{SD}=1.79$ & $\mathrm{SD}=1.86$ & DRD2 Tag1B & $\mathrm{F}_{2,510}=.32(\mathrm{p}=.726)$ & .001 & .101 \\
\hline & & & & & & cannabis/control x DRD2 Tag1B & $F_{2,510}=.65(p=.524)$ & .003 & .158 \\
\hline & & & & & & intercept & $F_{1,510}=923.72(p=.000)$ & .645 & 1.000 \\
\hline & & & & & & cannabis/control x DRD2 Tag1B & $\mathrm{F}_{2,510}=.02(\mathrm{p}=.976)$ & .0001 & .054 \\
\hline & & & & & & intercept & $F_{1,510}=991.95(p=.000)$ & .662 & 1.000 \\
\hline NEO FFI & $M=5.49$ & $M=6.08$ & $M=5.89$ & $M=5.78$ & $M=5.40$ & cannabis /control & $F_{1,510}=2.60(p=.107)$ & .005 & .363 \\
\hline Conscientiousness/scale & $\mathrm{SD}=2.25$ & $\mathrm{SD}=2.15$ & $\mathrm{SD}=2.00$ & $\mathrm{SD}=2.15$ & $\mathrm{SD}=2.80$ & $D R D 2 \operatorname{Tag} 1 B$ & $\mathrm{~F}_{2,510}=.49(\mathrm{p}=.610)$ & .002 & .131 \\
\hline & & & & & & cannabis/control x DRD2 Tag1B & $F_{2,510}=1.06(p=.348)$ & .004 & .235 \\
\hline
\end{tabular}


Table 5. Differences DRD2 Tag1D rs1800498 and STAI /NEO Five Factor Inventory between healthy control subjects and rural cannabis users

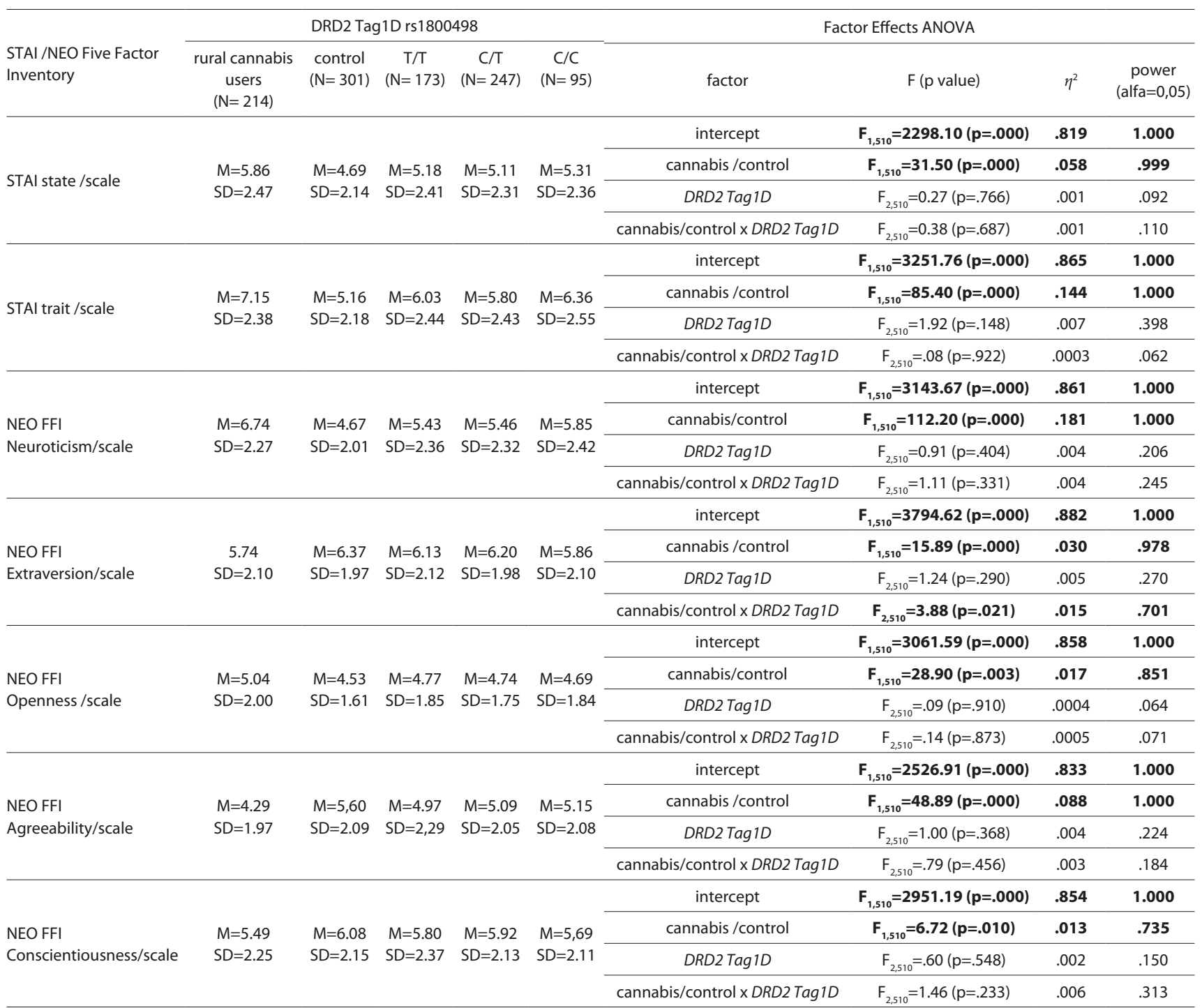

Significant between-group differences are marked in bold

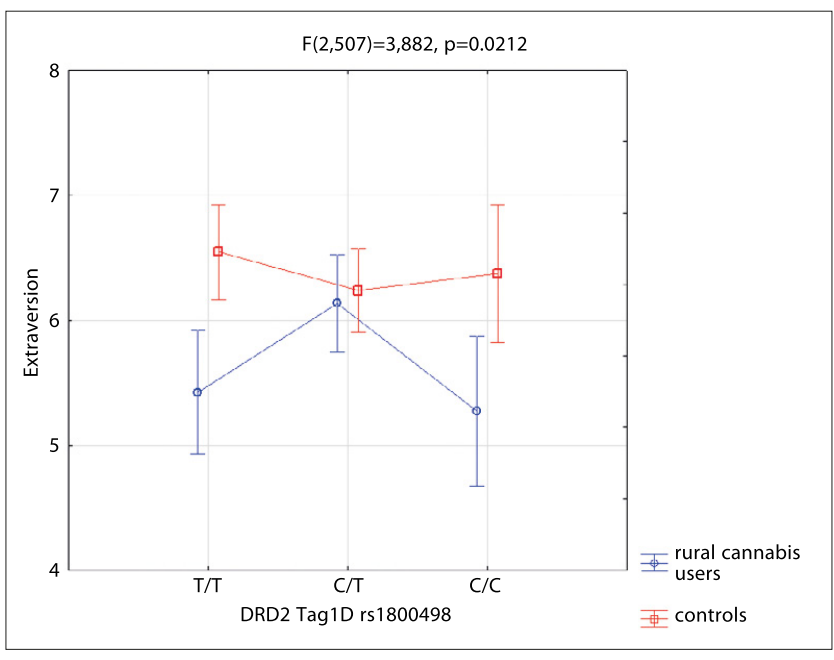

Figure 1. Tested groups' (rural cannabis users vs controls) DRD2 Tag1D rs1800498 polymorphism interaction for the NEO FFI Extraversion

\section{DISCUSSION}

The presented study was conducted among cannabis dependent patients with the investigation of two polymorphisms located in DRD2 gene, the Taq1D and Taq1B. The Big Five Questionnaire (NEO FFI) was also applied to evaluate personality traits, together with the STAI scale to measure anxiety and its modulating aspects in substance dependence occurrence.

Since marijuana addiction ought to be treated holistically, both the genetic factors - the influence of which has already been determined - and psychological factors that are an integral part of whole spectrum of addiction symptoms, were considered. The personality traits or anxiety level of the individual are conditioned by numerous decisions and behaviours in daily life, among them the decision to use or choose an addictive substance. Many such processes are influenced by impulse or a high level of anxiety, or inability to cope with stress. The current multi-dimensional analysis partly allowed the observation of a correlations in this area. It was seen that the scores of STAI inventory were significantly different between the study group and the controls. Dependent 
subjects were characterized with a higher anxiety trait as well as state scores. For both polymorphism, a variant interaction was observed for anxiety as a trait and as a state in the ANOVA model. A characteristic feature of anxiety disorders seemed to be that they often occurred simultaneously with substance dependence, and observed more often in families with a history of problems with substance use [4]. When comparing individuals affected with substance disorders and their family history of dependence with the controls, a higher number of anxious-impulsive personality traits were observed in the first group. Because of the fact the anxious-impulsive personality traits may be treated as probable endophenotype conditioning, the vulnerability of, e. g. cocaine or amphetamine dependence occurrence, the individuals with increased anxiety were more prone to the development substance dependence $[53,54]$. There are many studies that noted the relationship between anxiety traits measured by STAI and dependence [55]. A study from 2014 emphasized that addicted patients represented an increased score, not only in STAI inventory, but also in the depression scale, and lower in the stress tolerance scale [56]. It is worth mentioning that clinical, as well as research data, suggest that the ability to deal with stress or a bad mood are one of the most common motives of psychoactive substance usage among heavy abusers [57].

When comparing the controls and the study group, it can be observed that the scores of the NEO Five Factor Inventory scale of Neuroticism, the scores for Openness are significantly higher, whereas the scores on the NEO Five Factor Inventory scale of Extraversion and Conscientiousness are significantly lower. Both polymorphisms considered in the study show a variant interaction for all traits measured by the NEO-FFI in ANOVA model. What is even more important is that studies emphasize a significant relationship between the trait of personality and problematic substance use. The higher stress sensitivity observed among individuals abusing psychoactive substances and their non-affected relatives, indicates the fact that neuroticism could be assumed as a endophenotype influencing substance use disorder. Terracciano et al. noted that high scores of neuroticism traits are also associated with the usage of other psychoactive substances, i.e. tobacco, heroin and cocaine [24]. It is worth considering that individuals who use marijuana are also low on the Conscientiousness scale, but average or high on the Openness scale, which is a characteristic feature of substance users. It should also be emphasized that the observation that all 6 factors of the neuroticism trait are also associated with tobacco, heroin and cocaine use [24].

In the case of tobacco smokers, researchers noticed that tobacco abstinence correlates with low scores on neuroticism and openness, whereas high scores of neuroticism and low scores on agreeableness and conscientiousness remained in correlated with the most negative outcomes, which include a greater number of cigarettes smoked per day [58].

However, there are reasons for also applying genetic factors within the dimension of the studied genetic polymorphisms in correlation with psychological factors among marijuana abuse individuals. For organism functioning in health (and, thus avoidance of psychoactive substances overuse), the personality component in connection with stress coping is the crucial element. Numerous scientific studies have also demonstrated the association of chosen polymorphic variants with psychosocial functioning and human behaviours $[59,60,61]$.
Polymorphisms Taq1B and Taq1A are considered to be a part of the haplotype that may be associated with the history of suicide attempts in alcohol-dependent subjects, compared with alcohol dependent subjects who did not have any record of suicidal attempts in their medical history [62].

In the current study, the Taq1B polymorphism was in correlation with the anxiety level in the study group. The study of De Ruyck et al. concerning Taq1B noted a significant association between Taq1B and nicotine dependence [63]. It emphasized the fact that patients with variant alleles of the DRD2 Taq1A or Taq1B polymorphism demonstrated a two or three times increased risk, respectively, identified as highly vulnerable to nicotine dependence. There is only one recent study concerning the role of DRD2 Taq1B polymorphism in nicotine dependence. The tested group of 91 white Americans did not allow the observation of a positive association between the two polymorphisms [64]. However, there exists a precise linkage between the Taq1A and Taq1B polymorphisms which indicated that the effect of Taq1B is dependent on Taq1A; hence, the correlation of the intronic Taq1B SNP may be influenced by the activity of Taq1A.

There exists only one observed association in the group which replaced nicotine with a simultaneous combination of venlafaxine for 6 weeks, and was found for DRD2 Taq1B polymorphism [30]. A higher risk of heroin dependence is theoretically correlated with the the T allele of rs1079597 (Taq1B) in the DRD2 gene [65].

The significance of DRD2 gene polymorphism noted in the current and other studies is also supported by biological aspects. The rs1079597 polymorphism of the DRD2 gene seems to be conditioned with a low density of the dopamine receptor [66]. The presence of A allele in polymorphisms rs1800497 of the ANKK1 and rs1076560 located in DRD2 - was associated with a reduced availability of the receptor [67]. It is also worth mentioning that the DRD2 occurred in 2 main splice molecular variants (mRNA) with different lengths. When comparing the D2 short form with the D2 long form, a shortage of exon 6 transcript was observe.

The results of the current study suggest an important function of intronic polymorphisms in the ration of 2 different transcription variants of the D2 receptor gene [68]. The variants rs1079597 and rs1800497 show, to some extend, similar association with other psychological disorders, and interestingly both influence $\mathrm{D} 2$ receptor bonding potential to a corresponding level $[69,70]$. It should also be emphasized that the meaning of rs1800498 (T/C) polymorphism, for which an association was observed between the studied groups (cannabis users vs. controls) and DRD2 Taq1D rs1800498, influences the results of the NEO FFI extraversion scale. Lower values of the NEO FFI Extraversion scale were observed in the group of cannabis users with $\mathrm{T} / \mathrm{T}$ and $\mathrm{C} / \mathrm{C}$ polymorphisms, compared to the control group. Whereas for $\mathrm{C} / \mathrm{T}$ polymorphism, no differences were observed between cannabis users and control group. Other authors have also searched for associations with addiction in the same area of interest.

Vereczkey et al. noted that haplotype analysis demonstrated a relationship of this polymorphism with various forms of addiction, among them heroin and nicotine addiction [71, 72]. Previous studies have also emphasized the relationship of this polymorphism with the prognosis and treatment in the case of schizophrenia occurrence [69]. One of the most recent studies by the authors of the current study demonstrated that 
an allelic variant $\mathrm{T}$ of the rs 1800498 polymorphism of the $D R D 2$ gene occurred significantly more frequently in opiate and cannabis addicts, compared with controls [73].

Nevertheless, the results of studies are contradictory. Fernàndez-Castillo et al. argued that they did not observe any association between Taq1B and cocaine dependency; similarly, Małecka et al. did not note any association between Taq1B and Taq1D with alcohol dependence $[74,75]$.

When considering other populations, no association between Taq1B and vulnerability to smoking was observed in a Thai male population, and no association was observed between Taq1B and cannabis addiction in a Turkish population $[76,77]$. A study conducted among a group of 97 ADS-treated patients of Chinese origin, among them were the group of 34 people with behavioural disorders and 63 without such disorders, observed associations with Taq1B polymorphism. The study revealed that the genotype A/A and A allele were present more often in the group of alcohol addicted patients with co-morbid behavioural disorders, than in the control group of healthy people [78]. This is exactly the reason why studies such as the current one considering psychological and genetic factors are necessary.

The polymorphisms considered in this study, as well as the psychological aspect, should also be of interest to other researchers. However, in most cases the analyses were performed separately, which justifies the necessity to combine the analysis of psychological factors with genetic factors, especially in the case of addictions.

\section{CONCLUSIONS}

The study shows differences in personality traits between the group using cannabis using and the controls. An interaction between genetic factors and personality traits were also detected. The motives, as well as the precise endophenotype and its relation with proper therapy choice, are still not known. Further analysis concerning more numerous groups, more psychometric tests and a higher number of candidate genes, are essential for achieving indisputable results.

\section{Acknowledgement}

This research was funded by National Science Center grant number UMO-2015/19/B/NZ7/03691.

\section{Conflicts of Interes}

The authors have no conflicts of interest to declare.

\section{REFERENCES}

1. Lynskey MT, Heath AC, Nelson EC, Bucholz KK, Madden PA, Slutske WS et al. Genetic and environmental contributions to cannabis dependence in a national young adult twin sample. Psychol Med. 2002; 32: 195-207.

2. Rhee SH, Hewitt JK, Young SE, Corley RP, Crowley TJ, Stallings MC. Genetic and environmental influences on substance initiation, use, and problem use in adolescents. Arch Gen Psych. 2003; 60: 1256-1264.

3. World Drug Report 2019; Division for Policy Analysis and Public Affairs, United Nations Office on Drugs and Crime: Vienna, Austria, 2019.

4. Hill M, Sternberg A, Suk HW, Meier MH, Chassin L. The intergenerational transmission of cannabis use: Associations between parental history of cannabis use and cannabis use disorder, low positive parenting, and offspring cannabis use. Psychol Addict Behav. 2018; 32: $93-103$.
5. Sternberg A, Hill ML, Suk HW, Meier M, Chassin L. Exploring Cannabis-Specific Parenting as a Mechanism of the Intergenerational Transmission of Cannabis Use and Cannabis Use Disorder. J Stud Alcohol Drugs. 2019; 80: 32-41.

6. Rothenberg WA, Sternberg A, Blake A, Waddell J, Chassin L, Hussong A. Identifying adolescent protective factors that disrupt the intergenerational transmission of cannabis use and disorder. Psychol Addict Behav. 2019. doi: 10.1037/adb0000511

7. Kendler KS, Ohlsson H, Sundquist J, Sundquist K. A Contagion Model for Within-Family Transmission of Drug Abuse. Am J Psychiatry. 2019; 176: 239-248.

8. Kendler KS, Ohlsson H, Sundquist K, Sundquist J. Within-family environmental transmission of drug abuse: a Swedish national study. JAMA Psychiatry. 2013; 70: 235-42.

9. Kosty DB, Farmer RF, Seeley JR, Gau JM, Duncan SC, Lewinsohn PM. Parental transmission of risk for cannabis use disorders to offspring. Addiction. 2015; 110: 1110-7.

10. Maes HH, Neale MC, Ohlsson H, Zahery M, Lichtenstein P, Sundquist K et al. A Bivariate Genetic Analysis of Drug Abuse Ascertained Through Medical and Criminal Registries in Swedish Twins, Siblings and HalfSiblings. Behav Genet. 2016; 46: 735-741.

11. Kendler KS, Maes HH, Sundquist K, Ohlsson H, Sundquist J. Genetic and family and community environmental effects on drug abuse in adolescence: a Swedish national twin and sibling study. Am J Psychiatry. 2014; 171: 209-17.

12. Gillespie NA, Aggen SH, Neale MC, Knudsen GP, Krueger RF, South $\mathrm{SC}$ et al. Associations between personality disorders and cannabis use and cannabis use disorder: a population-based twin study. Addiction. 2018; 113: 1488-1498.

13. Smolkina M, Morley KI, Rijsdijk F, Agrawal A, Bergin JE, Nelson EC et al. Cannabis and Depression: A Twin Model Approach to Comorbidity. Behav Genet. 2017; 47: 394-404.

14. Elliott L, Haddock CK, Campos S, Benoit E. Polysubstance use patterns and novel synthetics: A cluster analysis from three U.S. cities. PLoS One. 2019; 14: e0225273.

15. Morgan N, Daniels W, Subramaney U. Smoking heroin with cannabis versus injecting heroin: unexpected impact on treatment outcomes. Harm Reduct J. 2019; 16: 65.

16. Viola TW, Sanvicente-Vieira B, Kluwe-Schiavon B, Rothmann LM, Mélo-Pereira JVNE, Bicca C et al. Association Between Recent Cannabis Consumption and Withdrawal-Related Symptoms During Early Abstinence Among Females with Smoked Cocaine Use Disorder. J Addict Med. 2020. doi: 10.1097/ADM.0000000000000599

17. Shen Y, Lo-Ciganic WH, Segal R, Goodin AJ. Prevalence of substance use disorder and psychiatric comorbidity burden among pregnant women with opioid use disorder in a large administrative database, 2009-2014. J Psychosom Obstet Gynaecol. 2020: 1-7. doi: 10.1080/0167482X.2020.1727882

18. Thayer RE, YorkWilliams S, Karoly HC, Sabbineni A, Ewing SF, Bryan $\mathrm{AD}$ et al. Structural neuroimaging correlates of alcohol and cannabis use in adolescents and adults. Addiction. 2017; 112: 2144-2154.

19. Murad H, Moassas F, Jarjour R, Mukhalalaty Y, Al-Achkar W. Prenatal molecular diagnosis of $\beta$-thalassemia and sickle cell anemia in the Syrian population. Hemoglobin. 2014; 38: 390-3.

20. Serjeant GR, Vichinsky E. Variability of homozygous sickle cell disease: The role of alpha and beta globin chain variation and other factors. Blood Cells Mol Dis. 2018; 70: 66-77.

21. Young-Wolff KC, Sarovar V, Tucker LY, Goler NC, Alexeeff SE, Ridout KK, Avalos LA. Association of Depression, Anxiety, and Trauma With Cannabis Use During Pregnancy. JAMA Netw Open. 2020; 3: e1921333.

22. Mercado A, Rogers DL, Rodriguez CC, Villarreal D, Terracciano A, Nguyen-Finn K. Personality and Substance Use in Mexicans and Mexican-Americans. Int J Ment Health Addict. 2016; 14: 907-20.

23. Flory K, Lynam D, Milich R, Leukefeld C, Clayton R. The relations among personality, symptoms of alcohol and marijuana abuse, and symptoms of comorbid psychopathology: results from a community sample. Exp Clin Psychopharmacol. 2002; 10: 425-3.

24. Terracciano A, Löckenhoff CE, Crum RM, Bi-envenu OJ, Costa PT Jr. Five-Factor Model personality profiles of drug users. BMC Psychiatry. 2008; 8: 22.

25. Moraleda E, Ramírez López J, Fernández-Calderón F, Lozano ÓM, Diaz-Batanero C. Personality Traits among the Various Profiles of Substance Use Disorder Patients: New Evidence Using the DSM-5 Section III Framework. Eur Addict Res. 2019; 25: 238-247.

26. Pasman JA, Verweij KJH, Gerring Z, Stringer S, Sanchez-Roige S, Treur $\mathrm{JL}$, et al. GWAS of lifetime cannabis use reveals new risk loci, genetic 
overlap with psychiatric traits, and a causal effect of schizophrenia liability. Nat Neurosci. 2018; 21: 1161-1170.

27. Hryhorowicz S, Walczak M, Zakerska-Banaszak O, Słomski R, Skrzypczak-Zielińska M. Pharmacogenetics of Cannabinoids. Eur J Drug Metab Pharmacokinet. 2018; 43: 1-12.

28. Mechoulam R, Parker LA. The endocannabinoid system and the brain. Annu Rev Psychol. 2013; 64: 21-47.

29. Altun A, Yildirim K, Ozdemir E, Bagcivan I, Gursoy S, Durmus N. Attenuation of morphine antinociceptive tolerance by cannabinoid CB1 and CB2 receptor antagonists. J Physiol Sci. 2015; 65: 407-15.

30. Chiang YC, Lo YN, Chen JC. Crosstalk between dopamine $\mathrm{D}_{2}$ receptors and cannabinoid $\mathrm{CB}_{1}$ receptors regulates $C N R 1$ promoter activity via ERK1/2 signaling. J Neurochem. 2013; 127: 163-76.

31. Hartman CA, Hopfer CJ, Haberstick B, Rhee SH, Crowley TJ, Corley $\mathrm{RP}$ et al. The association between cannabinoid receptor 1 gene (CNR1) and cannabis dependence symptoms in adolescents and young adults. Drug Alcohol Depend. 2009; 104: 11-16.

32. Peters KZ, Oleson EB, Cheer JF. A Brain on Cannabinoids: The Role of Dopamine Release in Reward Seeking and Addiction. Cold Spring Harb Perspect Med. 2020; pii: a039305.

33. Patriquin MA, Bauer IE, Soares JC, Graham DP, Nielsen DA. Addiction pharmacogenetics: a systematic review of the genetic variation of the dopaminergic system. Psychiatr Genet. 2015; 25: 181-93.

34. Gallo EF. Disentangling the diverse roles of dopamine D2 receptors in striatal function and behavior. Neurochem Int. 2019; 125: 35-46.

35. Blum K, Noble EP, Sheridan PJ, Montgomery A, Ritchie T, Ozkaragoz $\mathrm{T}$ et al. Genetic predisposition in alcoholism: association of the D2 dopamine receptor TaqI B1 RFLP with severe alcoholics. Alcohol. 1993; 10: 59-67, doi: 10.1016/0741-8329(93)90054-r.

36. Noble EP, Blum K, Khalsa ME, Ritchie T, Montgomery A, Wood RC et al. Allelic association of the D2 dopamine receptor gene with cocaine dependence. Drug Alcohol Depend. 1993; 33: 271-285.

37. Robinson JD, Lam CY, Minnix JA, Wetter DW, Tomlinson GE, Minna JD et al. The DRD2 TaqI-B polymorphism and its relationship to smoking abstinence and withdrawal symptoms. Pharmacogenomics J. 2007; 7: 266-274. doi: 10.1038/sj.tpj.6500427

38. Smith SS, O'Hara BF, Persico AM, Gorelick DA, Newlin DB, Vlahov D et al. Genetic vulnerability to drug abuse. The D2 dopamine receptor TaqI B1 restriction fragment length polymorphism appears more frequently in polysubstance abusers. Arch Gen Psychiatry. 1992; 49: 723-727.

39. Lilienfeld SO, Watts AL, Francis Smith S, Berg JM, Latzman RD. Psychopathy Deconstructed and Reconstructed: Identifying and Assembling the Personality Building Blocks of Cleckley's Chimera. J Pers. 2015; 83: 593-610.

40. Sachs GS, Peters AT, Sylvia L, Grunze H. Polypharmacy and bipolar disorder: what's personality got to do with it? Int J Neuropsychopharmacol. 2014; 17: 1053-61.

41. Keuthen NJ, Tung ES, Tung MG, Curley EE, Flessner CA. NEO-FFI personality clusters in trichotillomania. Psychiatry Res. 2016; 239: 196-203.

42. Widiger TA, Coata PT. Personality Disorders and the Five-Factor Model of Personality; American Psychological Association: Washington, DC, USA, 2013.

43. Goldberg LR. An alternative "description of personality": The big-five factor structure. J Personal Soc Psychol. 1990; 59: 1216-1229.

44. Thompson ER. Development and Validation of an International English Big-Five Mini-Markers. Personal Individ Differ. 2008; 45: 542-548.

45. Matthews G, Deary IJ. Personality Traits; Cambridge University Press: Cambridge, UK, 1998.

46. Holmes A, Yang RJ, Lesch KP, Crawley JN, Murphy DL. Mice lacking the serotonin transporter exhibit 5-HT(1A) receptormediated abnormalities in tests for anxiety-like behavior. Neuropsychopharmacology. 2003; 28: 2077-2088.

47. Lesch KP, Bengel D, Heils A, Sabol SZ, Greenberg BD, Petri S, et al. Association of anxiety-related traits with a polymorphism in the serotonin transporter gene regulatory region. Science. 1996; 274: 1527-1531.

48. DeYoung CG, Peterson JB, Higgins DM. Sources of openness/intellect: Cognitive and neuropsychological correlates of the fifth factor of personality. J Personal. 2005; 73: 825-858.

49. John OP, Srivastava S. The big-five trait taxonomy: History, measurement, and theoretical perspectives. Handb Personal Theory Res. 1999; 2: 102-138.

50. Friedman HS, Schustack MW. Personality: Classic Theories and Modern Research; Person: London, UK, 2016

51. Guillén-Riquelme A, Buela-Casal G. Meta-analysis of group comparison and meta-analysis of reliability generalization of the State-Trait Anxiety
Inventory Questionnaire (STAI). Rev Esp Salud Publica. 2014; 88: $101-12$.

52. Costa P, McCrae RR. The Revised NEO Personality Inventory (NEOPI-R); Sage Publications Inc.: Thousand Oaks, CA, USA, 2008; Volume 2, pp. 179-198.

53. Ersche KD, Turton AJ, Chamberlain SR, Müller U, Bullmore ET, Robbins TW. Cognitive Dysfunction and Anxious-Impulsive Personality Traits Are Endophenotypes for Drug Dependence. Am J Psychiatry. 2012; 169: 926-936.

54. Vorspan F, Mehtelli W, Dupuy G, Bloch V, Lépine JP. Anxiety and substance use disorders: co-occurrence and clinical issues. Curr Psychiatry Rep. 2015; 17: 4.

55. Pietras T, Witusik A, Panek M, Szemraj, Gorski P. Anxiety, depression and methods of stress coping in patients with nicotine dependence syndrome. Med Sci Monit. 2011; 17: Cr272-276.

56. Özdel K, Ekinci S. Distress intolerance in substance dependent patients. Compr Psychiatry. 2014; 55: 960-965.

57. Hyman SM, Sinha R. Stress-related factors in cannabis use and misuse: implications for prevention and treatment. J Subst Abuse Treat. 2009; 36: $400-413$.

58. Hooten WM, Ames SC, Vickers KS, Hays JT, Wolter TD, Hurt RD, et al. Personality correlates related to tobacco abstinence following treatment. Int J Psychiatry Med. 2005; 35: 59-74.

59. Genetics of Personality Consortium, de Moor MH, van den Berg SM, Verweij KJ, Krueger RF, Luciano M, Arias Vasquez A, et al. Metaanalysis of Genome-wide Association Studies for Neuroticism, and the Polygenic Association With Major Depressive Disorder. JAMA Psychiatry. 2015; 72: 642-50.

60. Docherty AR, Moscati A, Peterson R, Edwards AC, Adkins DE, Bacanu SA, et al. SNP-based heritability estimates of the personality dimensions and polygenic prediction of both neuroticism and major depression: findings from CONVERGE. Transl Psychiatry. 2016; 6: e926.

61. Amin N, Schuur M, Gusareva ES, Isaacs A, Aulchenko YS, Kirichenko $\mathrm{AV}$, et al. A genome-wide linkage study of individuals with high scores on NEO personality traits. Mol Psychiatry. 2012; 17: 1031-41.

62. Jasiewicz A, Samochowiec A, Samochowiec J, Małecka I, Suchanecka A, Grzywacz A. Suicidal behavior and haplotypes of the dopamine receptor gene (DRD2) and ANKK1 gene polymorphisms in patients with alcohol dependence-preliminary report. PLoS One. 2014; 9: e111798. doi: 10.1371/journal.pone.0111798

63. De Ruyck K, Nackaerts K, Beels L, Werbrouck J, De Volder A, Meysman $\mathrm{M}$, et al. Genetic variation in three candidate genes and nicotine dependence, withdrawal and smoking cessation in hospitalized patients. Pharmacogenomics. 2010; 11: 1053-1063. 10.2217/PGS.10.75

64. Spitz MR, Shi HH, Yang F, et al. Case-control study of the D2 dopamine receptor gene and smoking status in lung cancer patients. J Natl Cancer Inst. 1998; 90: 358-363.

65. Zhang J, Yan P, Li Y, Cai X, Yang Z, Miao X, et al. A 35.8 kilobases haplotype spanning ANKK1 and DRD2 is associated with heroin dependence in Han Chinese males. Brain Res. 2018: 1688: 54-64. doi: 10.1016/j.brainres.2018.03.017

66. Jonsson EG, Nothen MM, Grunhage F, Farde L, Nakashima Y, Propping P, et al. Polymorphisms in the dopamine D2 receptor gene and their relationships to striatal dopamine receptor density of healthy volunteers. Mol Psychiatry. 1999; 4: 290-296.

67. Ritchie T, Noble EP. Association of seven polymorphisms of the D2 dopamine receptor gene with brain receptor-binding characteristics. Neurochem Res. 2003; 28: 73-82.

68. Moyer RA, Wang D, Papp AC, Smith RM, Duque L, Mash DC, et al. Intronic polymorphisms affecting alternative splicing of human dopamine D2 receptor are associated with cocaine abuse. Neuropsychopharmacology. 2011; 36: 753-762 doi: 10.1038/ npp.2010.208

69. Rampino A, Marakhovskaia A, Soares-Silva T, Torretta S, Veneziani F, Beaulieu JM. Antipsychotic Drug Responsiveness and Dopamine Receptor Signaling; Old Players and New Prospects. Front Psychiatry. 2019; 9: 702 .

70. Gluskin BS, Mickey BJ. Genetic variation and dopamine D2 receptor availability: A systematic review and meta-analysis of human in vivo molecular imaging studies. Transl Psychiatry. 2016; 6: e747.

71. Vereczkey A, Demetrovics Z, Szekely A, Sarkozy P, Antal P, Szilagyi A, et al. Multivariate analysis of dopaminergic gene variants as risk factors of heroin dependence. PLoS One. 2013; 8: e66592.

72. Preuss UW, Zill P, Koller G, Bondy B, Sokya M. D2 dopamine receptor gene haplotypes and their influence on alcohol and tobacco consumption magnitude in alcohol-dependent individuals. Alcohol Alcohol. 2007; 42: 258-266. 
73. Sznabowicz M, Jasiewicz A, Iskra-Trifunović J, Małecka I, Karakiewicz B, Kotwas A, et al. Case-control study analysis of DRD2 gene polymorphisms in drug addicted patients. Psychiatr Pol. 2018; 52: 1013-1022. doi: 10.12740/PP/85935

74. Fernàndez-Castillo N, Ribasés $M$, Roncero $C$, Casas $M$, Gonzalvo $B$, Cormand B. Association study between the DAT1, DBH and DRD2 genes and cocaine dependence in a Spanish sample. Psychiatr Genet. 2010; 20: 317-20. doi: 10.1097/YPG.0b013e32833b6320

75. Małecka I, Jasiewicz A, Suchanecka A, Samochowiec J, Grzywacz A. Association and family studies of DRD2 gene polymorphisms in alcohol dependence syndrome. Postepy Hig Med Dosw (Online). 2014; 68: 1257-63. doi: 10.5604/17322693.1127883
76. Suriyaprom K, Tungtrongchitr R, Harnroongroj T. Impact of COMT Val 108/158 Met and DRD2 Taq1B gene polymorphisms on vulnerability to cigarette smoking of Thai males. J Mol Neurosci. 2013; 49: 544-9. doi: 10.1007/s12031-012-9844-Z

77. Nacak M, Isir AB, Balci SO, Pehlivan S, Benlier N, Aynacioglu S. Analysis of dopamine D2 receptor (DRD2) gene polymorphisms in cannabinoid addicts. J Forensic Sci. 2012; 57: 1621-4 doi: 10.1111/j.15564029.2012.02169.x

78. Lu RB, Lee JF, Ko HC, Lin WW. Dopamine D2 receptor gene (DRD2) is associated with alcoholism with conduct disorder. Alcohol Clin Exp Res. 2001; 25: 177-184. 